Original Research

\title{
Leadership and Innovation in Family Business
}

\author{
Inggrid Oktavia ${ }^{1 *}$, Sujoko Efferin ${ }^{1}$, Noviaty Kresna Darmasetiawan ${ }^{1}$ \\ Fakultas Bisnis dan Ekonomika Universitas Surabaya, Raya Kalirungkut, Surabaya - Indonesia 60293 \\ *Corresponding author: noviatykd@staff.ubaya.ac.id
}

\begin{abstract}
This research is a basic research that discusses leadership style in family business and innovation. Family business as a phenomenon has been a strong topic of conversation in society since the late 1990s, especially in Indonesia. Family business is one of the factors affecting the current Indonesian economy. Family business is also one of the very big roles in creating employment. The research method used is a qualitative method by interviewing, observing, and analyzing documents to support the validity of the data. Family business is a business that is determined, managed, and regulated by one or more generations of families or family members, where the values, vision, and mission determined by the founder will be strictly guarded. Leadership style and type of company are factors that influence family business. In addition to leadership and innovation styles, how to manage and manage subordinates has an important role in the family business .
\end{abstract}

Keywords : leadership style, innovation, family business

Abstrak- Penelitian ini adalah penelitian dasar yang mengeksplorasi gaya kepemimpinan dalam bisnis keluarga dan inovasinya. Bisnis keluarga sebagai sebuah fenomena telah menjadi topik pembicaraan yang kuat di tingkat masyarakat sejak akhir 1990-an, terutama di Indonesia. Bisnis keluarga adalah salah satu faktor yang mempengaruhi perekonomian Indonesia saat ini. Bisnis keluarga juga menjadi salah satu peran yang sangat besar dalam menciptakan lapangan kerja. Metode penelitian yang digunakan adalah metode kualitatif dengan cara wawancara, observasi, dan analisis dokumen untuk mendukung validitas data. Bisnis keluarga adalah bisnis yang dimiliki, dikelola, dan diatur oleh satu atau lebih generasi keluarga atau anggota keluarga, di mana nilai-nilai, visi, dan misi yang ditetapkan oleh pendiri akan dijaga secara ketat. Gaya kepemimpinan dan jenis perusahaan merupakan faktor yang mempengaruhi inovasi bisnis keluarga. Selain gaya kepemimpinan dan inovasi, cara mengendalikan dan mengelola bawahan memiliki peran penting dalam bisnis keluarga.

Kata kunci : gaya kepemimpinan, inovasi, bisnis keluarga

\section{INTRODUCTION}

Family business has been a strong topic of conversation at a societal level since the late 1990s, especially in Indonesia. Family businesses are one of the factors that influence Indonesia's economy at this time. Family businesses also play a significant role in creating employment. Family businesses are owned, managed, and regulated by one or more family generations or family members, where the values, vision, and mission set by the founder will be maintained. As a business owned and controlled by the family, the management and performance of the company, both small and large scale, are much influenced by the vision and mission of the family. Family businesses have been honored for their employee oriented behavior. The overall reflections on the financial crisis stated that family businesses provide potential answer to market risks, as they are considered to be long term oriented, flexible, and vested with sufficient assets due to family ownership and altruistic behavior.

According to Indonesian Institute for Corporate and Directorship data on 2010, more than 95 percent of businesses in Indonesia are owned and controlled by several families. That means that family business activities contributing the most to national economic development. However, family business certainly does not escape the various problems that are sometimes difficult to solve. For example; there is distrust among family members, conflict in leadership succession, conflict in decision making, issue of next leader, differences in managerial mindset between the first generation and the next generation, and so on.

Leadership is a particularly important issue in family business for the following reasons. First, family firms differ from other businesses in that family firms may have non performance-oriented goals that take precedence over the goals of growth and profitability. This comparative ambiguity in goals and objectives complicates the leadership process within the family firm because leaders have to consider multiple factors beyond firm performance. Second, although compared to non-family firms, family firms may have a more centralized decision-making process, less formalized systems, more intimate communication, and a more long-term approach (Morris et al., 1997), they also exhibit a greater potential for sustained 
conflict among involved actors. Finally, the issue of succession is far more important for family firms than non-family firms. Family business leaders view succession as integral to the survival of the firm, while some researchers in executive succession have highlighted leader idiosyncrasies and situational differences (Rubenson \& Gupta, 1996).

As a result, it is not uncommon for a family business to deteriorate, even forced to close, due to a prolonged conflict within the family. So, the three main issues that often arise in family business are leadership, ownership, and management principles, both in the first generation and the next generation.

In a context of constant changes that occur at different speeds, innovation is not only an advantageous option but an imperative for survival. Innovation is transforming new ideas into results. This goes far beyond generating good ideas; it is a management process, unfortunately, largely ignored in business. The role of the family in the innovation and creativity of the family business is one that allows training the youth and young adults, to an activity of constant renewal. In short, family should be able to think about improving things constantly.

The topic of this research is Leadership in Family Business. The leadership style that will discussed in this research is transactional and transformational leadership style. The reason why transactional and transformational leadership style is choosen in this reasearch is researcher already know leadership style implemented in this company by having preliminary observation before.

The case company named CV. JT and located in Situbondo, East Java, Indonesia. This company work under PT. MPM regulations and permission as one of Astra Honda Motor dealer in Indonesia. The company used in this research is motorcycle retail business, which already existed for about 45 years and already had 3 dealer branches. This company was founded on 1970 by Mr. K (under disguised name). This company is highly regulated by PT. MPM in some aspect. This research is aimed to discover do the leadership style give any impacts to the innovation in this company and could help them to innovate in other aspect, for example service given to customers.

\section{Leadership}

For many years, culture has been claimed as an important element of organizational successful in the business world. Organizations take very different approaches to build quality work culture. For some organizations, quality of work culture has never mattered most. But in some organizations, quality of work culture is crucial to ensure the employees served a better service to the customers. In addition, quality culture will lead to harmonization in the workplace. In today's millennium, most of the successful organizations possessed great leaders and managers where they can monitor and supervise employees' behavior and performance. Excellent leader will lead employees to become more proactive and dynamic in executing their daily tasks. The leadership styles of leaders may influence quality of work culture in the organization.

Leadership is a process by which an individual influences working colleagues toward accomplishing common goals (Flynn, 2009:2). It involves influencing the participation of colleagues and providing guidance in a specified course to be navigated. According to Naidu and Van Der Walt (2005:2), an effective leadership style influences change and creates the impetus for transformation. The role played by a leader could be viewed as an influential change-agent. Banerji and Krishnan (2000:406) view leadership as a process whereby leaders develop a shared vision and set the tone to influence the behaviours of all in the organisation towards achieving common values. The shared vision creates alignment by developing a common mental model for employees to follow. Jones and Rudd (2007:522) define leadership as a relationship between leaders and followers within a social group. It entails supplying a vision, creating power and using this power for individuals to realize the vision.

Leadership is also viewed as a process of initiating, executing and evaluating aspects of 
organisational change. Literature suggests that leadership styles are situational and have enhanced individual and organisational success in many ways. Leaders actively create the tempo and provide guidelines for employees to follow (Naidu \& Van Der Walt, 2005:1). Literature also cites leadership as a process which ordinary people use to bring about the best from themselves and others. It entails empowering others to make decisions, thereby translating the vision into reality through effective execution of the strategy. It is also viewed as a process of influencing people to do more than is normally expected of them.

\section{Leadership style}

Mullins (1999) defined leadership style as "the way in which the functions of leadership are carried out and the manner that a manager chooses to behave towards employee". Leadership style is a form of cross situational behavioural consistency. It refers to the manner in which a leader interacts with his or her subordinates. Leadership styles are the approaches used to motivate followers. Leadership styles should be selected and adapted to fit organizations, situations, groups, and individuals. It is thus useful to possess a thorough understanding of the different styles as such knowledge increases the tools available to lead effectively. While many leadership styles, attributes, traits and philosophies account for the extensive literature surrounding leadership (House, Hanges, Javidan, Dorfman, \& Gupta, 2004; Howell \& Costley, 2006; Judge \& Piccolo, 2004; Mandell \& Pherwani, 2003; Eagly, JohannesenSchmidt, \& Van Engen, 2003; Carless, 1998; Hofstede, 1980).

Leadership style is viewed as the combination of traits, characteristics, skills and behaviours that leaders use when interacting with their subordinates. Leadership styles also can be used to identify four different types of leaders which have been widely accepted and used, which centred around Mc Gregor's Theory ' $X$ and $Y$ ' assumptions, are democratic, autocratic, dictatorial, and laissez faire leadership styles. The styles of leadership include bureaucratic, laissez-faire, charismatic, democratic, transactional and transformational.

\section{Transactional leadership style}

The word transactional is derived from the word transaction. In the dictionary the definition of transaction can be found as; "an instance or process of transacting something". The definitions of transactional by Bass (1985) and Judge and Piccolo (2004) all describe some sort of transaction between people. It can be said that transactional refers to the transaction of resources between leader and subordinate, offering in this transaction what the leader and subordinate wants.

Transactional leadership is based on classical principles of exchange with followers who are part of interactions and therefore are rewarded for meeting predefined standards and performance. Transactional leadership is focused on maintaining the status quo, so transactional leadership present traditional approach of leadership.

Transactional leadership style commonly used in conditions where the focus of leaders focused on the basic process control, organization and short-term planning. Transactional leadership involves motivating and directing followers, appealing to their own interests. The power of the leader comes from formal authority and responsibility in the organization. The main task of the followers to respect the instructions of leaders. The leader provides rewards and punishments in the organization of its legitimacy. Transactional leadership is, in essence, oriented on monitoring organization, processes and outcomes in the market.

Transactional Leadership, also known as managerial leadership, focuses on the role of supervision, organisation, and group performance; transactional leadership is a style of leadership in which the leader promotes compliance of his followers through both rewards and punishments. Unlike transformational leadership, leaders using the transactional approach are not looking to change the future, they are looking to merely keep things the same. These leaders pay attention to followers' work in order to find faults and deviations. This type of leadership is effective in crisis and emergency situations, as well as when projects need to be 
carried out in a specific fashion. Within the context of Maslow's hierarchy of needs, transactional leadership works at the basic levels of need satisfaction, where transactional leaders focus on the lower levels of the hierarchy. Transactional leaders use an exchange model, with rewards being given for good work or positive outcomes. Conversely, people with this leadership style also can punish poor work or negative outcomes, until the problem is corrected.

Transactional leaders are focused on short-term goals, standards, procedures, rules and control. Creativity, vision and generating of new ideas are not represented. The efficiency (cost reduction) is the key variable of leadership competencies. Followers are motivated only by rewards and punishments, and the utility over money dominates the leader-followers. Transactional leadership is based on the assumption that employees are motivated by the best system of rewards and punishments.

\section{Transformational leadership style}

Transformational leadership enhances the motivation, morale, and performance of followers through a variety of mechanisms. These include connecting the follower's sense of identity and self to the project and the collective identity of the organization; being a role model for followers that inspires them and makes them interested; challenging followers to take greater ownership for their work, and understanding the strengths and weaknesses of followers, so the leader can align followers with tasks that enhance their performance. Warrilow (2012) identified four components of transformational leadership style:

1) Charisma or idealised influence

The degree to which the leader behaves in admirable ways and displays convictions and takes stands that cause followers to identify with the leader who has a clear set of values and acts as a role model for the followers.

2) Inspirational motivation

The degree to which the leader articulates a vision that is appeals to and inspires the followers with optimism about future goals, and offers meaning for the current tasks in hand.

3) Intellectual stimulation

The degree to which the leader challenges assumptions, stimulates and encourages creativity in the followers by providing a framework for followers to see how they connect [to the leader, the organisation, each other, and the goal] they can creatively overcome any obstacles in the way of the mission.

4) Personal and individual attention

The degree to which the leader attends to each individual follower's needs and acts as a mentor or coach and gives respect to and appreciation of the individual's contribution to the team. This fulfils and enhances each individual team members' need for self fulfilment, and self worth and in so doing inspires followers to further achievement and growth.

A transformational leader is a person who stimulates, inspires and transform followers to achieve extraordinary outcomes. He/she pay attention to the concern and developmental needs of individual followers, they change followers' awareness of issues by helping them to look at old problems in a new way, and they are able to arouse, excite and inspire followers to put out extra effort to achieve group goals. Transformational leadership theory is all about leadership that creates positive change in the followers whereby they take care of each other's interests and act in the interests of the group as a whole (Warrilow, 2012).

\section{Family Business}

The use of different definitions is a major problem in family firm research. Although 
studies analyze related topics, the use of different family firm definitions makes the comparability of these results difficult. One of the biggest challenges of developing a general definition is the heterogeneity of family firms. Family firms are a unique group of organizations, but they also differ within this group. The involvement of the family in the management and ownership structure of the firm is unique to each family firm and thus it cannot be seen as constant factor.

The components of involvement approach treats family involvement as a sufficient condition in order to define a firm as a family firm, the essence approach treats it only as a necessary condition. Following the components-of-involvement approach, a firm can be defined as a family firm when a family is the owner, the firm is family managed, or the firm is controlled by a family. If one of these three characteristics applies to a firm, it can be defined as a family firm. The essence approach is more restrictive and defines firms only.

\section{Innovation}

Innovation is an idea, a practice or an object that is perceived as new by an individual or unit of adoption, developed as a way of responding to a change in the environment or a way of influencing it. It constitutes a way to change the organization (Damanpour, 1991), it can have as output either new ways of doing things or new products, services, or techniques (Porter, 1990) and it has been considered an important factor for entrepreneurship (Schumpeter, 1934). Innovation can be defined as production or adoption, assimilation, and exploitation of a value-added novelty in economic and social spheres; renewal and enlargement of products, services, and markets; development of new methods of production; and establishment of new management systems. It is both a process and an outcome.

There are perhaps at least as many definitions of innovation management as there are of leadership. According to a rather broad definition by Baregheh, Rowley, and Sambrook (2009: 1334), "Innovation is the multi-stage process whereby organizations transform ideas into improved products, service or processes, in order to advance, compete and differentiate themselves successfully in their marketplace". However, no conceptualization that does not qualify innovation as a kind of change. Therefore, change is broadly understood as the genus of innovation, and innovation is broadly understood as a subset of change (there is no innovation without change). Differences in the conceptualization of innovation result from different specifications of change with regard to substance (what is the subject of change) and impact (what types of change count as innovation).

\section{Innovation and Family Business}

Innovation is the development of a new product or the adoption of a new product or the implementation of a creative idea. This can particularly help in solving problems that can affect the profits of the company, etc. Innovativeness has been linked to proactivity and risk taking. It essentially means to divert from the usual practices and try new ideas and experiment with these ideas. According to Gedajlovic \& Carney (2012), innovation is the most important factor in the growth of small family firms. Normally it has been suggested that family firms do not experiment due to financial constraints and the different dynamics of family members. However, recent research has thrashed these assumptions, proving that family firms tend to act more boldly and more often they exhibit bold moves and entrepreneurial innovativeness, especially if they are smaller firms as compared to larger firms. Smaller firms tend to adopt new ideas and technology more quickly as compared to large, well established firms (Zahra, 2005). Smaller firms can do this by introducing new products that display this innovativeness in the market. One more interesting point to note is that family firms have a longer standing relationship between the family members and the firm itself. This has further proven that because of this long standing relationship, family firms plan more for their future and thus, they are more exposed and willing to accept innovation, since innovation always takes time to develop properly (Upton, Teal \& Felan, 2001). 
Innovation is also referred to as not only introducing new products, but also as adopting newer technological and business practices that are more market-oriented, creating newer skills and more competencies. A factor that contributes directly to innovativeness is knowledge of the members of the firm which can increase competitiveness in firms, meaning new ways to try to lower the overall costs of production and keeping all the labor satisfied as well. If a family firm's resources are more knowledge based, then it is more likely that the firm will move towards innovation because it will be able to apply this knowledge to recognize and utilize opportunities for innovativeness.

It has been proven that family firms have better advantage when it comes to applying innovativeness and they are therefore, more exposed to the competing advantage in the market. This was proven by measuring performance, looking at the long term outlook and the advantages that were gained through innovativeness. Although, technologically family firms might be less inclined to test their innovativeness since the idea of using capital does come in to play, it should be noted that innovativeness is more likely in family firms as they are more exposed to it.

\section{Theoretical Model}

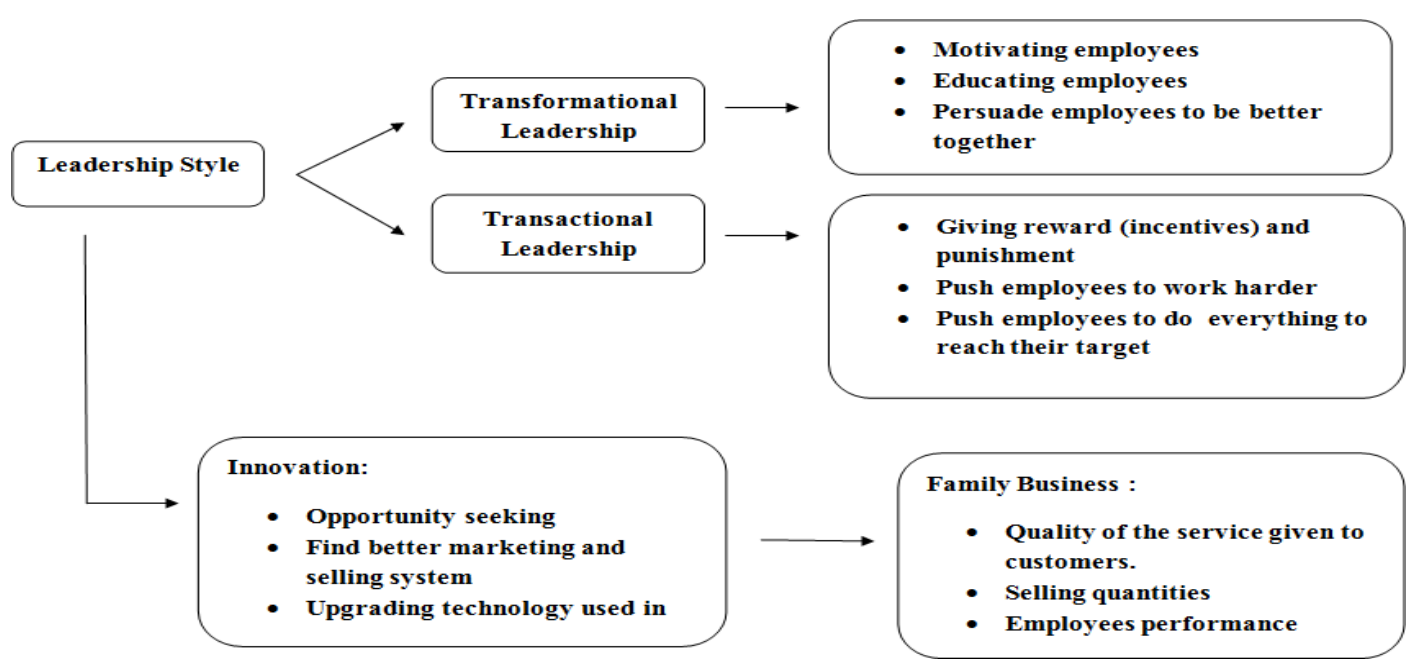

In prior research explained the relation of transformational leadership style and innovation, or the relation of transactional leadership style and innovation. It is hard to find the relation of the relation of transactional, transformational leadership style and innovation in family business. In this research author is trying to explain how transactional and transformational leadership style implemented in a family business and how the leadership styles influencing the innovation in that company.

\section{Methods}

Issues discussed by researcher is about leadership in family business and innovation. Method used in this research is qualitative research to determine how to find, collect, process, and analyze data from the research. In this research, researcher will doing observation and interviews to individuals in CV. JT related to their leader's leading style.

This is research conducted to find out what kind of leadership style which suit the best for family business and help them to innovate. Therefore, the researcher uses exploratory research. Exploratory research is research conducted in order to find how leadership style help CV. JT to innovate. There are three main research question that have to be answered :

1. What kind of leadership implemented by the leaders ?

2. How was CV. JT innovating? 


\section{How do the leaders solve problems they have?}

\section{Result and Discussion}

Leadership style have an important role in CV. JT, especially in how they manage their employees to give their best performance. Based on interviews and observations that has been done in CV. JT, CV. JT leaders tend to use transactional leadership to keep their employees and subordinates work hard and gives their best performance for CV. JT. Leaders tend to give reward and punishment to motivate their employees or subordinates.

In CV. JT, employees performance, especially in sales and marketing department is measured by amount of motorcycle they able to sold. For those who can reach their target, they get incentives as their reward, and those who can not reach their target, there are no punishment for them, they only didn't receive their incentives, but, the director of this company assume, that can't receive incentives also a punishment for them and it will help pushed them to work harder to reach their target.

CV. JT managers is also giving punishment for all of their subordinates who have a bad work attitude, for example, late come to work and often absent. The managers give all of their subordinates penalty for all who comes late and there is no toleration. They should pay for the penalty that already approved since they are starting work in CV. JT. The term is also the same for everyone who absent, they should pay penalty if they are absent more than 3 times.

But, the managers in CV. JT is also implement a transformational leadership style, beacause, aside from set the rules and punishment, the managers in CV. JT is trying to give their employees good example by their attitude and also motivate their subordinate to become better by giving motivation words. The managers try to always come earlier than other and rarely absent. The punishment term also applied for the managers, all of the managers should pay for the penalty if they are late or absent more than 3 times. Beside giving their subordinates punishment, all of the managers also always ask to their subordinates privately, if they are comes late or absent, why they they are late or absent, are they have problem, and try to help them and giving them solutions. The managers also told their subordinates that they need each other to develop CV. JT.and try to show their subordinates that they care to them in order to make all of the subordinates feels they are important for both their managers and CV. JT.

Leadership style is undirectly is also influence innovation in CV. JT. Because of the reward which in form of incetives (additional money) given by the managers and director, all of the employees in CV. JT is trying to maximalized facilities around them to support and help them increasing the amount of motorcyle they sell. For example, aside from spread out brocures to all possible place which have good prospect, joining as much as possible event, etc, they also implement a digital marketing, which is trying maximalize the existance of social media, they promote CV. JT and motorcycle from facebook, instagram, and twitter as well. They are giving as much information as possible there. The are sharing the new products explanation, events that will hold by CV. JT, and promotion that CV. JT have in that periode. They also share their contact number in order to make customers easier and faster to reach them and get informations needed related to products they wants to know or buy and all the services that the customers will get.

But, innovation in CV. JT is limited around the management, marketing, and technologies used in the company. All of innovation related to the motorcycle (design, motorcyle technology, types, etc) is not included as CV. JT authority, because in this case CV. JT is only reseller.

Incentive system (reward and punishement system) is a monetary gift provided to an employee based on performance, which is thought of as one way to entice the employee to continue delivering positive results. Incentive pay may come in the form of a bonus, profitsharing, or commission. Incentive system is implemented in CV. JT to help the leaders, whether 
they are director or managers to control, manage and motivate their employees. There are two kind of incentive, which are positive incentive which can be called as reward and negative incentive which can be called as punishment, but both of them have the same functions, which are control, manage, and motivate employees.

Reward can push and motivate employees to work harder and give their best to achieve the target given. While punishment indirectly can motivate them work harder. For example, this month they can't receive additional money (sales bonus) because they didn't reach their target, because of it, they will try harder to reach their target, so next month they can receive bigger sales bonus.

Punishment also can help the leaders to manage and control their subordinates. By requires all of the employees to pay penalty if they comes late or absent more than 3 times, it can help to manage the employees to come to work on time and minimized the possibilites of employees to absent without important or urgent reasons.

CV. JT is trying to build a good communication between leaders and subordinates in order to make leaders easier to manage and control their subordinates. Communication also could help them to deliver what each other wants and achieve each other goals and it can help to make sure the employees goals and the companys goals is the same. With good communication they also can solve their problems faster, by find solutions and face it together. They also can minimize the chance of the same mistake happened more repeatedly by told the subordinates what are their mistakes, why it can be stated as mistakes, etc and keep remind them to not do the same mistakes. Good communication can be built by built a good relation and make the subordinates comfortable to each other and ecourages them to share, so they can willing to share what problem they have or faced to other employees or their manager so they can find the solution together and handle it faster and easier with the help of other people.

\section{Conclusion}

Family businesses are one of the factors that influence Indonesia's economy at this time. Family businesses also become one of a very big role in creating employment. During the research, writer found that beside leadership style which implemented in the company, the type of company's business is also one of determinant factor which influence innovation in a company. In this case, CV. JT is a company which some of their regulation is regulated by other company (PT. AHM). CV. JT innovation is limited on their service for their customers or way of marketing, because innovation related to the products is out of CV. JT authority.

Beside the leadership style and innovation CV. JT, writer also found that the way the leaders control and manage their subordinates is having an important role to the family business existance. The leaders, whether he is director or managers, they should know which method is suitable to implement for manage and control the employees below them.

\section{References}

Banerji, P \& Krishnan, VR 2000, 'Ethical preferences of transformational leaders: An empirical investigation', Leadership and Organisation Development Journal, 28(1), 405-403.

Baregheh, A, Rowley, J \& Sambrook, S 2009, 'Towards a multidisciplinary definition of innovation', Management Decision, 47(8), 1334.

Bass, BM 1985, Leadership and performance beyond expectations, Free Press, New York.

Carless, S 1998, 'Gender difference in transformational leadership: An examination of superior, leader and subordinate perspective', Sex Roles, 39, 887-902.

Damanpour, F 1991, 'Organizational innovation: A meta-analysis of effects of determinants and moderators', Academy of Management Journal, 34(3), 555-590.

Eagly, AH, Johannesen-Schmidt, MC \& Van Engen, ML 2003, 'Transformational, transactional and laissez-faire leadership styles: A meta- analysis comparing women and men', American Psychological Association, 129, 569-91. 
Flynn, SI 2009, 'Transformational and transactional leadership', Research Starters Sociology, 16.

Gedajlovic, E \& Carney, M 2012, 'Markets, hierarchies, and families: Toward a transaction cost theory of the family firm', Entrepreneurship Theory and Practice, 34(6), 1145-1172.

Hofstede, G 1980, Culture's consequences: International differences in work-related values, Sage, Beverly Hills, CA.

House, R, Hanges, P, Javidan, M, Dorfman, P \& Gupta, V 2004, Culture, leadership, and organizations: The globe study of 62 societies, Sage Publications, Thousand Oaks, CA.

Howell, J \& Costley, D 2006, Understanding behaviors for effective leadership, Pearson Prentice Hall, Upper Saddle River, NJ.

Jones, DW \& Rudd, RD 2007, 'Transactional, transformational or Laissez-Faire leadership: An assessment of College of Agriculture Academic Program Leaders (Deans) Leadership Styles', Proceedings of the AAAE Research Conference, Vol. 3.

Judge, TA \& Piccolo, RF 2004, 'Transformational and transactional leadership: A meta-analytic test of their relative validity', Journal of Applied Psychology, 89(5), 755-768.

Mandell, B \& Pherwani, S 2003), 'Relationship between emotional intelligence and transformational leadership styles: A gender comparison', Journal of Business and Psychology, 17, 387-404.

Mullins, L 1999, Management and organizational behavior, Pitman Publishing, London.

Naidu, J \& Van Der Walt, MS 2005, 'An exploration of the relationship between leadership styles and the implementation of transformation interventions, SA Journal of Human Resource Management, 3(2), 1-10.

Porter, M 1990, The competitive advantage of nations, Macmillan, London, England.

Schumpeter, JA 1934, Theory of economic development, Harvard University Press, Cambridge, MA.

Upton, N, Teal, EJ \& Felan, JT 2001, 'Strategic and business planning practices of fast growth family firms', Journal of Small Business Management, 39(1), 60-72.

Warrilow, S 2012, Transformational leadership theory -the 4 key components in leading change \& managing change.

Zahra, SA 2005, 'Entrepreneurial risk taking in family firms', Family Business Review, 18(1), 2340.

\section{BIBLIOGRAPHY}

Banjoko, S 2006, Managing corporate reward systems, Pumark Nigeria Limited, Lagos.

Bass, B \& Avolio, B 1993, Improving organizational effectiveness through transformational leadership, Saga Publications.

Biddle, I 2005, 'Approaches to management: Leadership styles', Businessdate, 13(3), 14.

Johnson, M 1995, Managing in the new millennium, Butterworth- Heinmeann, Lagos.

Luthans, F 1992, Organisational Behaviour, 9th ed, McGraw Hill, Singapore.

Mohammad Mosadegh Rad, A., \& Hossein Yarmohammadian, M 2006, 'A study of relationship between managers' leadership style and employees' job satisfaction', Leadership in Health Services, 19(2), 11-28.

Nikezić, S \& Marković, S 2011, 'Transformational leadership as a factor profound changes', 11th International Conference Research And Development In Mechanical Industry RaDMI 2011, SaTCIP (Scientific and Techical Center for Intellectual Property) Ltd., Sokobanja, Serbia.

Rubin, RS, Munz, DD \& Bommer, WH 2005, 'Leading from within: Effects of emotional recognition and personality on transformational leadership behavior', Academy of Management Journal, 845-858.

Smith, E (n.d.),Transactional leadership, Barry University, Florida, Unpublished Manuscript. 
Yukl, G 1999, 'An evaluation of the conceptual weaknesses in transformational and charismatic leadership theories, Leadership Quarterly, 10(2), 285-305. 